\title{
NUTRITION PECULIARITIES AND ADDICTIONS OF YOUNG WOMEN WITH DIABETES MELLITUS TYPE 1 AND HEALTHY PERSONS AGED 18-25 YEARS AND THEIR INTERPLAY WITH BODY COMPOSITION
}

\author{
Sandrija Čapkauskienė, Daiva Vizbaraitė, Joana Garlavičiūtė, NilanaVaitkevičiūtė \\ Lithuanian Academy of Physical Education, Kaunas, Lithuania
}

\begin{abstract}
Research background and hypothesis. Nutrition therapy is important for the prophylaxis of diabetes, managing existing diabetes, and preventing or at least slowing the rate of development of diabetes complications. We suppose that nutrition peculiarities and addictions of young diabetic women interplay with their body composition.

Research aim was to determine nutrition peculiarities and addictions of young girls with diabetes mellitus type 1 and healthy persons aged 18-25 years and their interplay with body composition.

Research methods. The study included 24 healthy young women (mean age: $20.2 \pm 1.2$ ), and 14 young women with type 1 diabetes (mean age: $21.9 \pm 0.8$ ). Anthropometric measurements were performed, and a questionnaire to determine nutrition peculiarities and addictions was used.

Research results. The values of BMI, waist circumference, waist to hip ratio index were statistically significantly higher in women with type 1 diabetes $(p<0.05)$. Vegetable oil for cooking was reported by $86 \%$ of diabetic and $58 \%$ of healthy women $(\mathrm{p}<0.05) .50 \%$ of diabetics responded that they always had their meals at regular hours, and only $4 \%$ of healthy women pointed out irregular hours of their meals $(p<0.05)$. Evaluations of addictions did not reveal any significant difference $(\mathrm{p}>0.05)$. Nutrition peculiarities and addictions did not have any effect on the body composition of the research participants.

Discussion and conclusions. BMI was within normal limits, however, this indicator was significantly higher in women with type 1 diabetes. Waist circumference and waist to hip ratio were also significantly higher in women with type 1 diabetes mellitus. Young diabetic women reported having meals at regular hours more often. Vegetable oil for cooking was used in both groups; additionally, healthy women were more likely to consume home-grown foods. When evaluating addictions, a significant difference between groups was not observed. Nutrition peculiarities and addictions did not have any effect on body composition.
\end{abstract}

Keywords: anthropometrical data, questionnaire, smoking, alcohol.

\section{INTRODUCTION}

$\mathrm{D}$ iabetes belongs to a group of metabolic diseases characterized by hyperglycemia resulting from defects in insulin secretion, insulin action, or both. Chronic hyperglycemia of diabetes is associated with long-term damage, dysfunction, and failure of different organs, especially the eyes, kidneys, nerves, heart, and blood vessels (ADA, 2011).

Nutrition therapy is important for the prophylaxis of diabetes, managing existing diabetes, and preventing or at least slowing the rate of development of diabetes complications. For individuals with type 1 diabetes, insulin therapy should be integrated into an individual's dietary and physical activity pattern. (ADA, 2008). Central to dietary management in type 1 diabetus mellitus is monitoring carbohydrate intake and balancing carbohydrate intake and insulin levels (Bantle et al., 2008). Close adherence to carbohydrate intake recommendations is 
associated with better glycemic control (Patton et al., 2007; Mehta et al., 2008). Moreover, a mismatch between carbohydrate intake and insulin can result in immediate and long-term complications from hypo- and hyperglycemia (Silverstein et al., 2005). It is also important for patients to consume a healthy diet. Although there are no disease-specific nutrition guidelines for youth with type 1 diabetes mellitus, the young are at risk for dyslipidemia and cardiovascular disease. Several epidemiology studies have demonstrated that many young people with type 1 diabetes mellitus already had abnormal lipid levels and other risk factors for cardiovascular disease (Kershnar et al., 2006; Overby et al, 2007; Margeirsdottir et al, 2008). Thus, it is recommended that youth with type 1 diabetes mellitus eat a healthy diet according to the American diabetes association (ADA, 2008). It calls for a diet that incorporates fruits and vegetables, whole-grain foods, and foods low in fat. The American Diabetes Association further recommends that all youth with type 1 diabetes mellitus should attempt to consume no more than $7 \%$ of energy from saturated fat (Bantle et al., 2008).

\section{RESEARCH METHODS}

The object of the study and contingent. The study group included 24 healthy young women (mean age: $20.2 \pm 1.2$, height $1.70 \pm 0.1 \mathrm{~cm}$, body mass $-59.6 \pm 8.0 \mathrm{~kg}$ ) and 14 young women with type 1 diabetes (mean age: $21.9 \pm 0.8$, height $1.70 \pm$ $0.1 \mathrm{~cm}$, body mass $-68.1 \pm 7.5 \mathrm{~kg}$ ).

Methods. Anthropometric measurements were performed. Height and weight of the research participants were measured according to the recommendations of the World Health Organization (WHO) using equipment suitable for medical studies. Body mass index (BMI) was defined body mass in kilograms dividing by height in meters squared. Measurements of byceps, triceps, subscapular and suprailiac skinfold thickness were performed, and then, sums of the skinfold thickness according to N. D. Muth (2011) were calculated. Waist and hip circumference were also measured. The results of waist circumference were evaluated according to G. A. Bray (2004) method. Calculated waist to hip ratio allowed to evaluate a risk for cardiovascular diseases (Welborn, 2003).

Questionnaire. The studied filled in a factical nutrition and life stylequestionnaire (Kadziauskienè et al., 1999) which contained 31 questions including the following domains: 7 questions - the place of residency, marital status, 11 questions - nutrition, 5 questions - smoking, 3 questions about alcohol consumption, 3 questions about physical activity, 2 questions about anthropometric data. Six questions involved demographic data.

Statistics. Statistical analysis was performed using Microsoft Office Excel 2003 and the software SPSS package. The following statistical parameters were analyzed: mean indicators and standard deviations, the percentage of maximal values, Spearman's rho correlation coefficient. Differences were considered as statistically significant if $\mathrm{p}<0.05$.

\section{RESEARCH RESULTS}

Body composition. A value of BMI was statistically significantly higher in women with type 1 diabetes compared to healthy controls $23.3 \mathrm{~kg} / \mathrm{m}^{2}$ vs. $20.7 \mathrm{~kg} / \mathrm{m}^{2}(\mathrm{p}<0.05)$ (Figure 1). However, according to the WHO criteria, BMI in both groups was within normal limits.

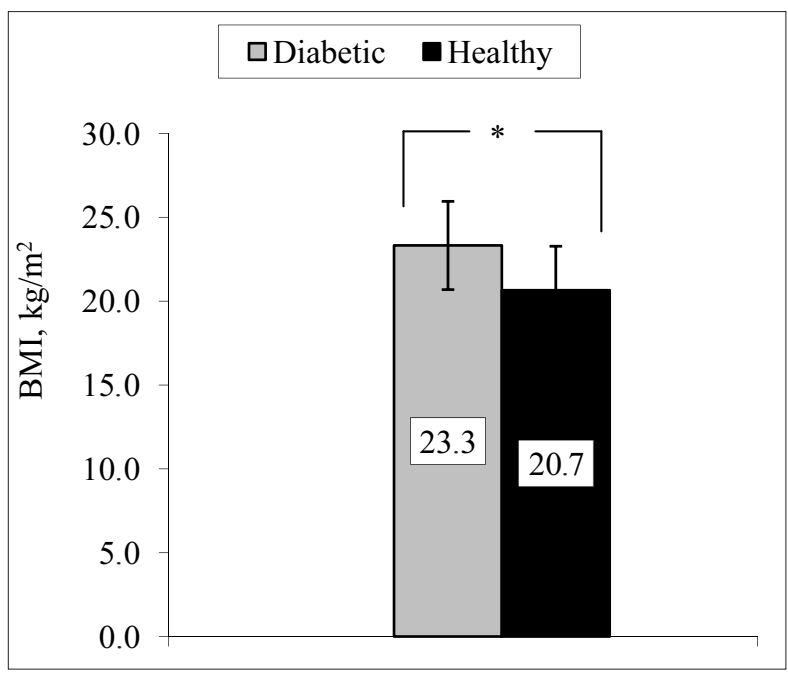

Figure 1. Body mass index $\left(\mathrm{kg} / \mathrm{m}^{2}\right)$ in diabetic and healthy women

Note. $*-p<0.05$.

Calculation of the fat body mass percentage revealed that in women with type 1 diabetes it was $31.8 \%$, in healthy $-29.5 \%(\mathrm{p}>0.05)$. Based on N. D. Muth method (2001), the body fat percentage in all subjects was evaluated as moderate. Given waist circumference, it was $70 \mathrm{~cm}$ in diabetic women, and $62 \mathrm{~cm}$ in healthy young women $(\mathrm{p}<0.05)$ (Figure 2). It suggests that insufficient weight was found in healthy controls (Bray, 2004), and women with type 1 diabetes had normal weight. 


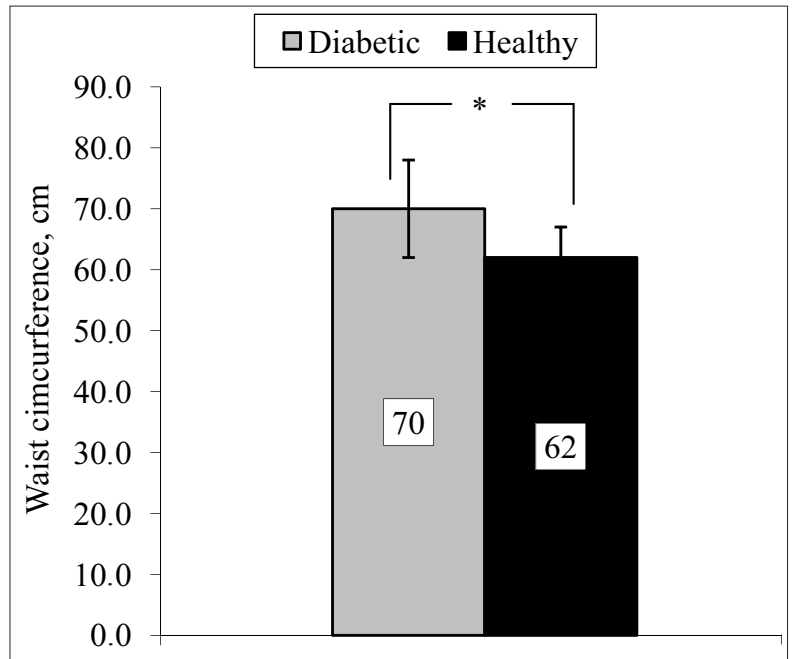

Figure 2. Waist circumference $(\mathrm{cm})$ of diabetic and healthy young women

Note. ${ }^{*}-\mathrm{p}<0.05$.

Low waist to hip ratio showed that diabetic and healthy young women were not at risk for cardiovascular diseases. Waist to hip ratio in diabetic women was 0.78 , in healthy controls -0.75 $(\mathrm{p}<0.05)$. The results are presented in Figure 3.

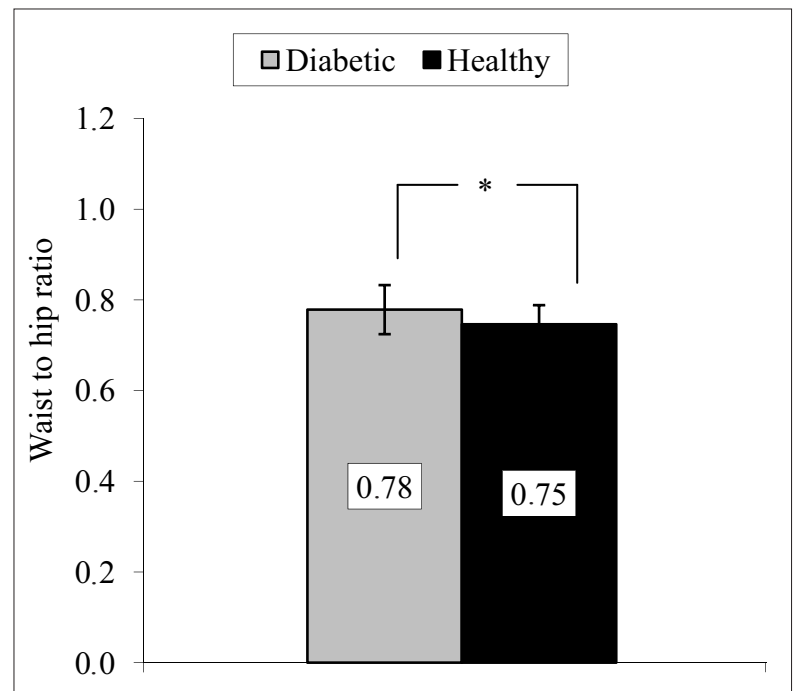

Figure 3. Waist to hip ratio in diabetic and healthy women Note. ${ }^{*}-\mathrm{p}<0.05$.

Nutrition. The majority of women used vegetable oil for cooking: $86 \%$ of women with type 1 diabetes and $58 \%$ of healthy women $(\mathrm{p}<0.05)$. Fewer participants chose butter $-7 \%$ of diabetic and $38 \%$ of healthy women $(\mathrm{p}<0.05)$. The lowest part of all fats accounted for animal fats in both groups. In diabetic group only $7 \%$ of women reported using animal fats, and in control group $4 \%$ of respondents (Figure 4.).

Given eating frequency, 1-2 times per day was not reported by diabetic women, whereas in the control group $21 \%$ of women stated that they had meals 1-2 times per day. Intake of food 3-4 times per day was pointed out by $57 \%$ of women with type 1 diabetes and $46 \%$ of healthy respondents. Diabetic women (43\%) had meals 5-6 times per day while such eating frequency was indicated by $33 \%$ of healthy women $(\mathrm{p}<0.05)$.

Women with type 1 diabetes (50\%) responded that they always had their meals at regular hours, another equal part of diabetic women reported not always having meals at the same time. The answer to the same question was positively marked by $96 \%$ of healthy women and only $4 \%$ pointed out irregular hours of their meals $(\mathrm{p}<0.05)$ (Figure 5.).

Analysis of correlation between nutrition and home-grown foods showed that $50 \%$ of women with type 1 diabetes responded that their nutrition did not include any of such products. Nobody in diabetic group responded that their nutrition depended on home-grown foods very much, whereas the positive answer was given by $25 \%$ of healthy women $(\mathrm{p}<0.05)$ (Figure 6).

Addictions. Fewer than 20 cigarettes per day were smoked by $7 \%$ of women with type 1 diabetes, whereas a positive answer was received by $29 \%$ of healthy respondents. In diabetic group 93\% were non-smokers, and in control group - $71 \%$ $(\mathrm{p}>0.05)$. Neither diabetic, nor healthy women reported smoking more than 20 cigarettes per day.

Consumption of strong alcohol beverages 2-3 times per month were surprisingly reported by $57 \%$ of women with type 1 diabetes. Healthy women (29\%) responded having strong alcohol beverages once per week. Strong alcohol beverages were not used by $14 \%$ diabetic and $8 \%$ healthy respondents $(\mathrm{p}>0.05)$.

Given frequency of wine intake between groups, $57 \%$ of young women with type 1 diabetes and only by $21 \%$ of healthy respondents reported consuming wine 2-3 times per month. Healthy young women $(17 \%)$ and nobody in diabetic group reported never consuming wine.

There was a statistically significant correlation between indicators of body composition in young women with type 1 diabetes and healthy women. A strong and statistically confident correlation between BMI and fat body mass percentage was determined: $r=0.752, p<0.01$ vs $r=0702$, $\mathrm{p}<0.01$. Interplay between BMI and waist circumference in diabetic group was moderate and strong, statistically significant in healthy group: $\mathrm{r}=0.629, \mathrm{p}<0.05$ vs $\mathrm{r}=0.781, \mathrm{p}<0.01$. There 


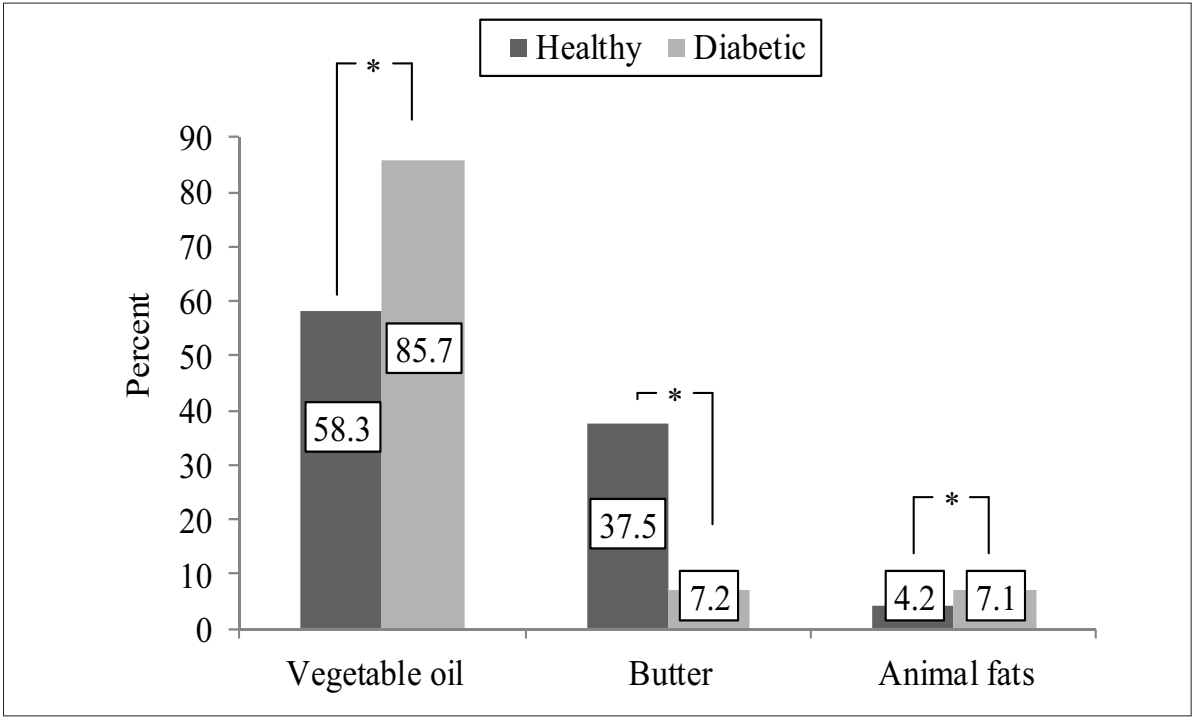

Figure 4. Structure of fat use by diabetic and young women

Note. ${ }^{*}-\mathrm{p}<0.05$.

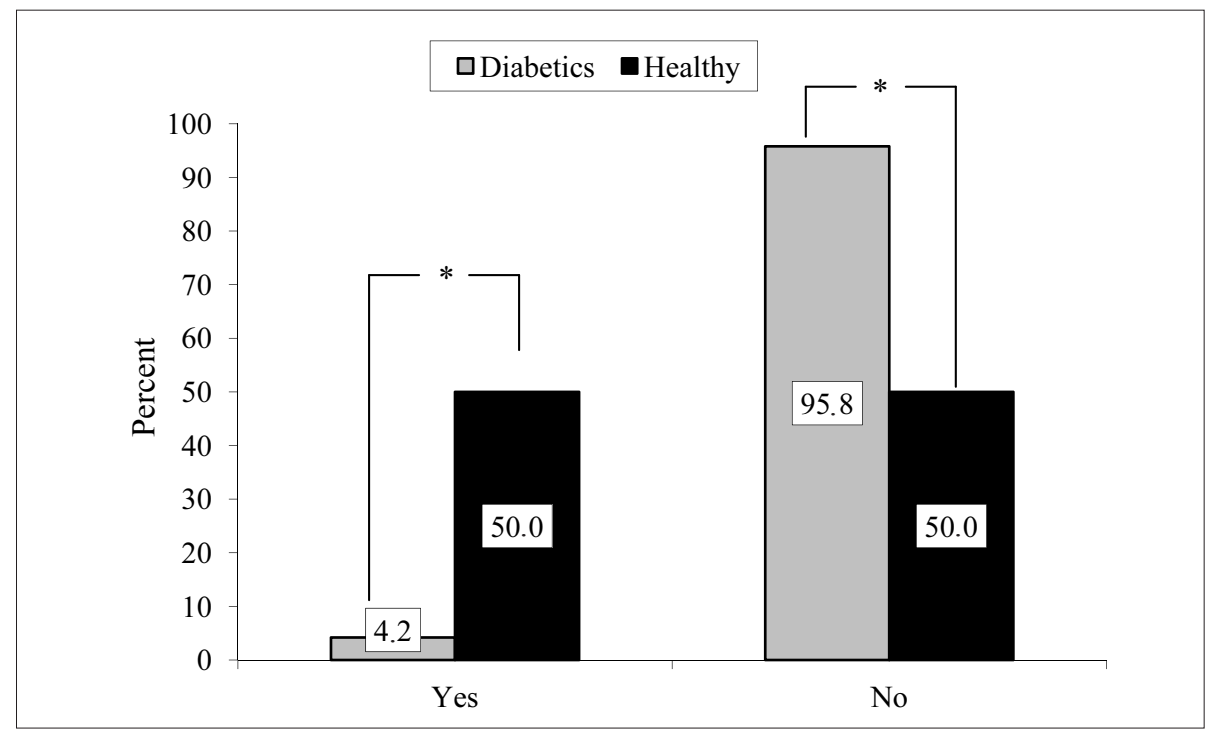

Figure 5. Percentage of diabetic and healthy women having their meal at regular hours

Note. ${ }^{*}-\mathrm{p}<0.05$

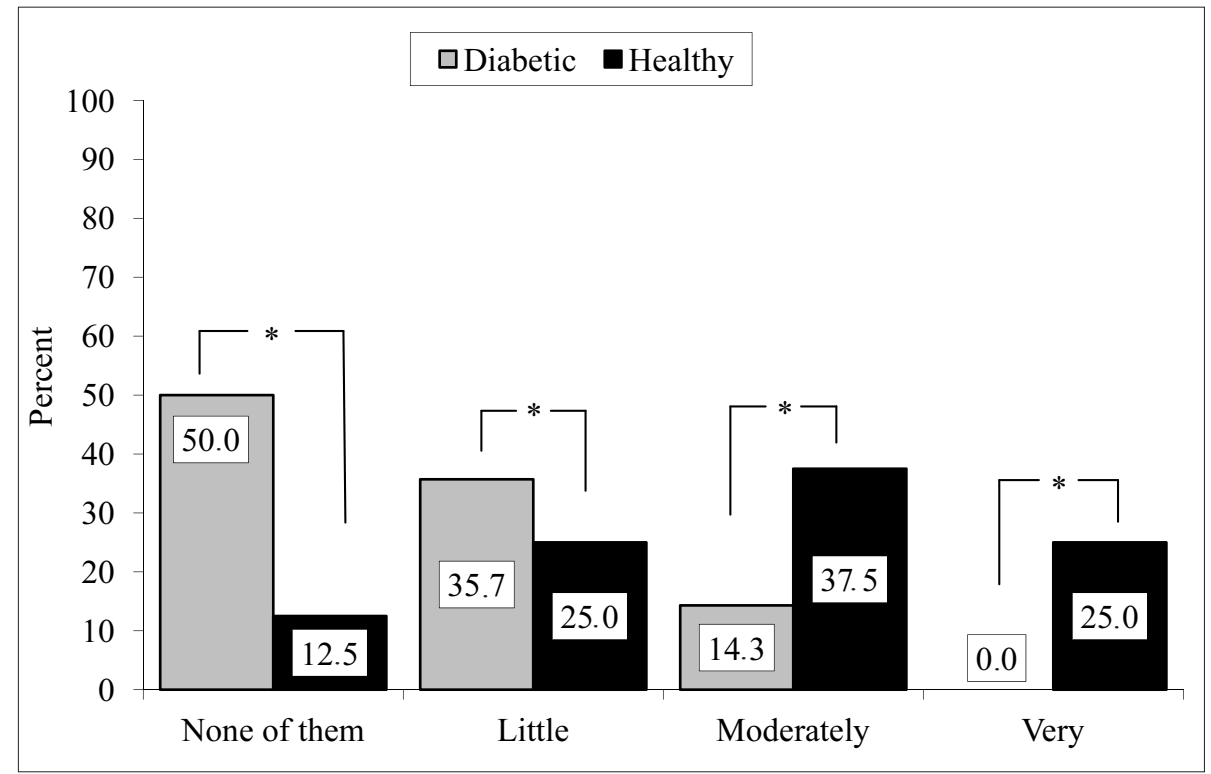

Figure 6. Correlation between nutrition and home-grown foods in diabetic and healthy women

Note. ${ }^{*}-\mathrm{p}<0.05$ 
Figure 7. Frequency of strong alcohol beverages in diabetic and control groups

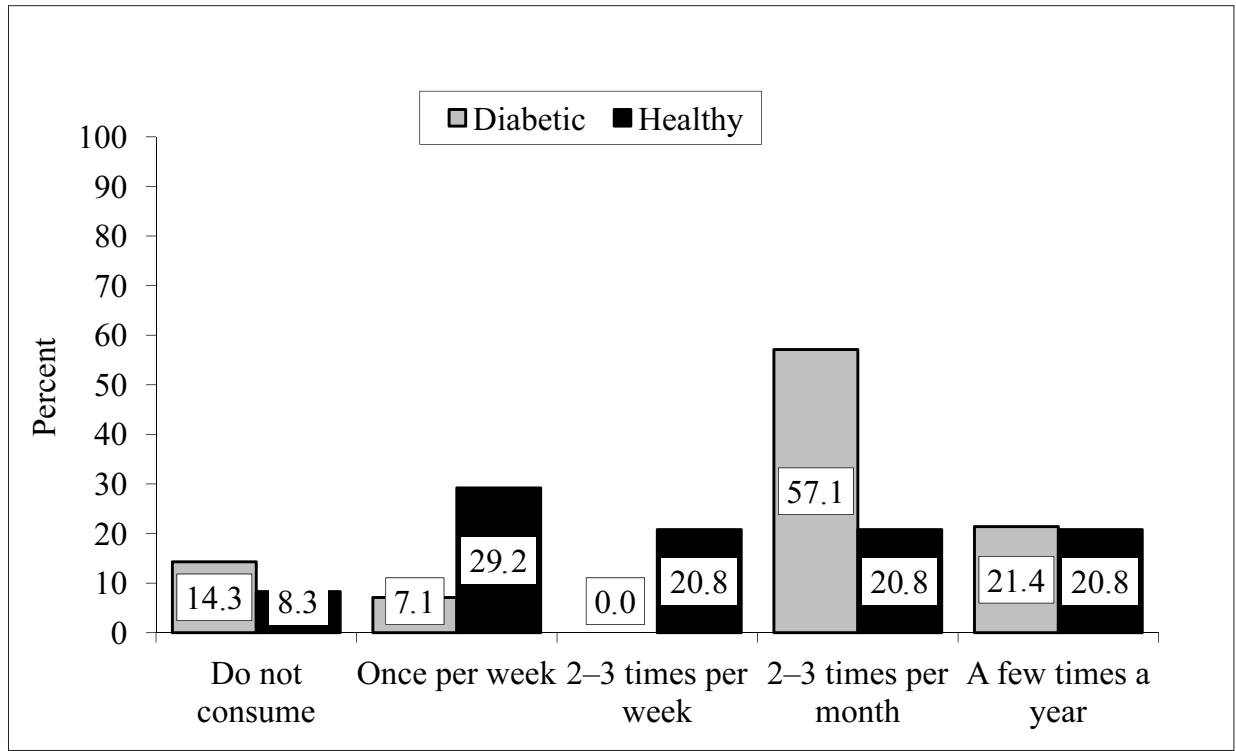

Figure 8. Frequency of wine intake by diabetic and healthy women

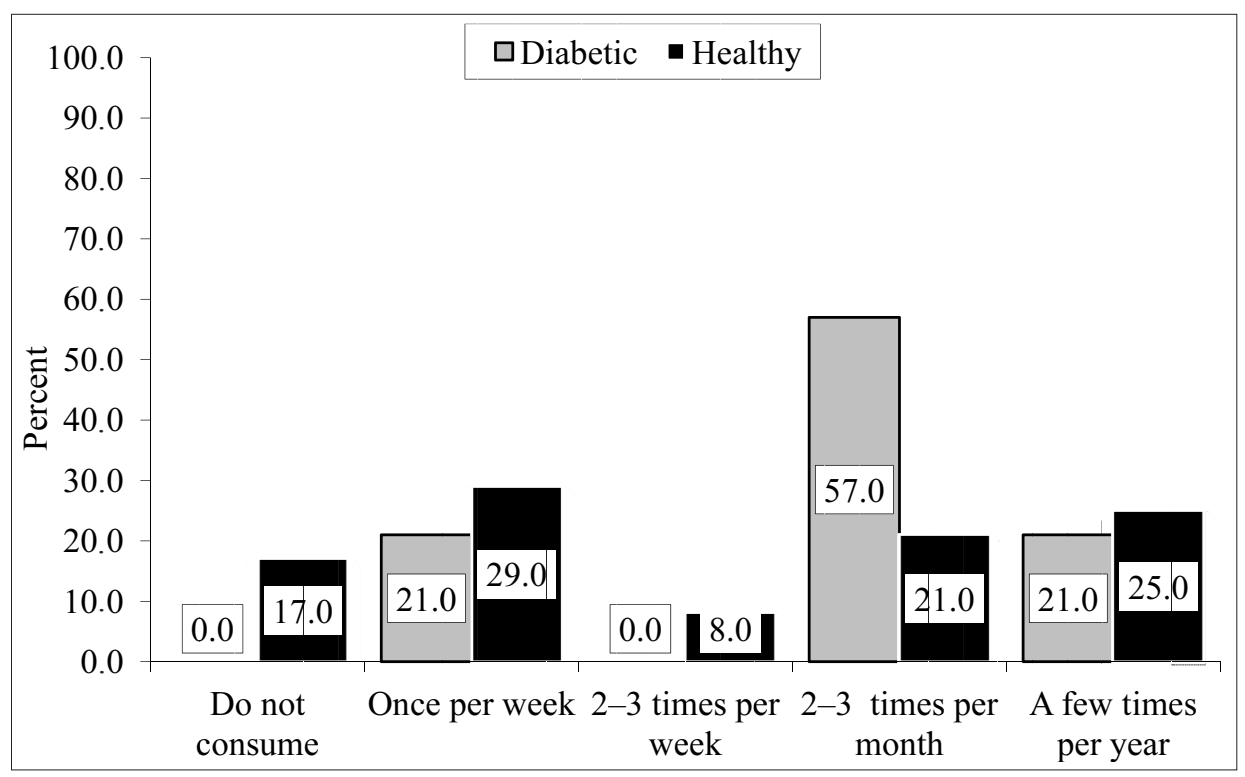

was a moderately strong correlation between fat body mass percentage and waist circumference in both groups: $\mathrm{r}=0.536, \mathrm{p}<0.05 \mathrm{vs} \mathrm{r}=0.610$, $\mathrm{p}<0.01$. A statistically strong correlation between waist to hip ratio was found in diabetic group: $\mathrm{r}=0.803, \mathrm{p}<0.01$. Relationship between nutrition peculiarities, addictions and body composition in both groups was not determined.

\section{DISCUSSION}

According to the WHO recommendations, means of body mass index (BMI) of women in both groups were attributed to the second category - normal body weight - from $18.5 \mathrm{~kg} / \mathrm{m}^{2}$ to $24.9 \mathrm{~kg} / \mathrm{m}^{2}(\mathrm{p}<0.05)$. Although BMI of diabetic women was higher, it was still within normal limits. This was also confirmed by other researchers, as
S. Särnblad (2006) and C. M. Ingberg (2003). When comparing the values of BMI with the results of the questionnaire, a negative correlation between BMI and eating frequency as well as meals at regular hours was determined suggesting that BMI value of the subjects who had meals more frequently and followed regular hours of eating was lower. As L. D. Ritchie (2012) states, lower eating frequency is associated with bigger absorption of fats. Such correlation between healthy young women was not observed. Most young women with type 1 diabetes had meals more times per day compared with healthy women: we did not determine diabetic women who had meals only 1-2 times a day, whereas in healthy group $21 \%$ of women reported having meals 1-2 times per day. Moreover, the majority $(96 \%)$ ) of diabetic women had daily regular hours of eating, and only $50 \%$ of healthy 
Table. Interplay between anthropometric parameters and the data of the questionnaire for diabetic and healthy women by Pearson's correlation coefficient

\begin{tabular}{|l|c|c|c|c|c|c|c|c|}
\hline \multirow{2}{*}{ Indices } & \multicolumn{5}{|c|}{ Diabetic women } & \multicolumn{4}{c|}{ Healthy women } \\
\cline { 2 - 9 } & BMI & $\begin{array}{c}\text { Percentage of } \\
\text { fat body mass }\end{array}$ & $\begin{array}{c}\text { Waist } \\
\text { circumference }\end{array}$ & $\begin{array}{c}\text { Waist to } \\
\text { hip ratio }\end{array}$ & BMI & $\begin{array}{c}\text { Percentage of } \\
\text { fat body mass }\end{array}$ & $\begin{array}{c}\text { Waist } \\
\text { circumference }\end{array}$ & $\begin{array}{c}\text { Waist to } \\
\text { hip ratio }\end{array}$ \\
\hline BMI & 1.00 & $\mathbf{0 . 7 5 2 * *}$ & $\mathbf{0 . 6 2 9 *}$ & 0.30 & 1.00 & $\mathbf{0 . 7 0 2 * *}$ & $\mathbf{0 . 7 8 1 * *}$ & -0.01 \\
\hline $\begin{array}{l}\text { Percentage of fat body } \\
\text { mass }\end{array}$ & $\mathbf{0 . 7 5 2 * *}$ & 1.00 & $\mathbf{0 . 5 3 6 *}$ & 0.43 & $\mathbf{0 . 7 0 2 * *}$ & 1.00 & $\mathbf{0 . 6 1 0 * *}$ & 0.03 \\
\hline Waist circumference & $\mathbf{0 . 6 2 9 *}$ & $\mathbf{0 . 5 3 6 *}$ & 1.00 & $\mathbf{0 . 8 0 3 * *}$ & $\mathbf{0 . 7 8 1 * *}$ & $\mathbf{0 . 6 1 0 * *}$ & 1.00 & 0.32 \\
\hline Waist to hip ratio & 0.30 & 0.43 & $\mathbf{0 . 8 0 3 * *}$ & 1.00 & -0.01 & 0.03 & 0.32 & 1.00 \\
\hline Use of fat & -0.21 & 0.10 & -0.09 & -0.10 & 0.08 & -0.11 & 0.20 & -0.10 \\
\hline $\begin{array}{l}\text { Eating frequency (times } \\
\text { per day) }\end{array}$ & -0.46 & -0.28 & 0.04 & 0.23 & -0.40 & -0.18 & -0.37 & -0.19 \\
\hline $\begin{array}{l}\text { Having meal at regular } \\
\text { hours }\end{array}$ & -0.47 & -0.12 & -0.31 & 0.10 & -0.03 & 0.22 & -0.21 & 0.23 \\
\hline $\begin{array}{l}\text { Nutrition correlation } \\
\text { therewasbetween }\end{array}$ & -0.13 & -0.22 & 0.03 & -0.08 & -0.23 & -0.10 & -0.18 & -0.13 \\
\hline $\begin{array}{l}\text { Mean number of } \\
\text { cigarettes smoked per } \\
\text { day }\end{array}$ & -0.22 & -0.18 & -0.17 & 0.06 & 0.04 & 0.06 & 0.01 & 0.07 \\
\hline $\begin{array}{l}\text { Consumption of strong } \\
\text { alcohol beverages }\end{array}$ & 0.29 & 0.05 & 0.43 & 0.14 & 0.34 & 0.36 & 0.30 & 0.14 \\
\hline $\begin{array}{l}\text { Frequency of wine } \\
\text { intake }\end{array}$ & -0.30 & -0.10 & -0.34 & 0.02 & 0.20 & 0.408 & 0.28 & 0.19 \\
\hline
\end{tabular}

Note. ${ }^{*}-\mathrm{p}<0.05, * *-\mathrm{p}<0.01$.

women followed regular eating pattern. Similar data were obtained by researchers R. Stukas and V. Dobrovolskij (2009), who studied nutrition of the Estonian students - the study results showed that their nutrition pattern was irregular. Only $43.4 \%$ of the subjects had meals 3 times per day, and $90 \%$ of Estonian students had snacks between meals.

Fat body mass percentage of young women with type 1 diabetes was higher than that of healthy controls $(31.0 \%$ compared with $29.5 \%$, respectively $(p>0.05)$. However, the evaluation of fat mass percentage according to Natalie Digate Muth (2011) method showed that both groups were attributed to the fourth category - the moderate value. It was also determined that there was a linear correlation between the fat mass percentage and waist circumference of all women - young women who had higher fat body mass percentage, had also a greater waist circumference. A linear correlation between fat body mass percentage and waist to hip ratio was found in diabetic women $(\mathrm{p}<0.05)$. However, a similar correlation in healthy controls was not determined.

Mean waist circumference was greater in diabetic women $(70 \mathrm{~cm})$ compared with healthy participants $(62 \mathrm{~cm})(\mathrm{p}<0.05)$. Evaluation of the results obtained according to G. A. Bray (2004) method showed that diabetic young women had a normal body weight, whereas in healthy controls it was insufficient. A positive correlation in diabetic group between consumption of strong alcohol beverages and waist circumference was determined; women who had strong alcohol beverages more frequently had also higher value of waist circumference. The study revealed that $57 \%$ of diabetic women had intake of strong alcohol 2-3 times per month. Most healthy women (29\%) consumed strong alcohol once per week. Strong alcohol intake was not pointed out by $14 \%$ of diabetic and $8 \%$ of healthy young women. However, this difference was not statistically confident $(p>0.05)$, therefore, a hypothesis that consumption of strong alcohol beverages may have an effect on waist circumference was rejected. This fact was also confirmed by A. Norkus et al. (2007): A patient with type 1 diabetes who has a normal body weight, and well controlled diabetes may occasionally have alcohol, but it should not be included into nutrition plan. If alcohol is daily consumed, its energetic value should be included into nutrition plan. A correlation between alcohol and waist circumference was not found in healthy 
controls. The study performed in Brasilia (Ferreira et al., 2008) showed that there was a relationship between alcohol intake for a long period and waist circumference - waist circumference was the largest in individuals who consumed more alcohol. This relationship was the strongest in the subjects who had intake of beer. Although a correlation between waist circumference and intake of strong alcohol was observed, it was the weakest compared with other alcohol beverages.

Evaluation of waist to hip ratio is associated with cardiovascular diseases - the study performed in the United States of America revealed that 35\% of individuals with type 1 diabetes died of coronary artery disease under the age of 55 years compared with $4-8 \%$ of persons without diabetes. Type 1 diabetes is one of the risk factors for cardiovascular diseases (Krishnan et al., 2011). Waist to hip ratio significantly correlated with percentage of fat body mass and waist circumference in diabetic women the greater the waist to hip ratio, the higher the values of percentage of fat body mass and waist circumference.

Addictions. Apart from alcohol intake, another addiction that is common among youth smoking-was evaluated. It was determined that $7 \%$ of diabetic and $29 \%$ of healthy women smoked $(\mathrm{p}<0.05)$. Although a significant difference of smoking women between diabetic and control groups (the number of smoking women was 4 times bigger than that of diabetic women), a significant correlation between smoking and body composition was not found. In 2008 the study carried out in central Thailand showed that BMI and waist circumference of smoking young people were smaller compared to non-smoking research participants of the same age (Jitnarin, 2008).

\section{CONCLUSIONS AND PERSPECTIVES}

1. Body mass index of all studied women aged 18-25 years was within normal limits, however, this indicator was higher in young women with type 1 diabetes. Waist circumference and waist to hip ratio were also significantly higher in diabetic women.

2. Eating frequency of women with type 1 diabetes was also significantly higher that that of healthy controls. The majority in both groups used vegetable oil for cooking. Healthy young women were more dependent on home-grown foods. Evaluation of addictions did not reveal any significant difference.

3. Nutrition peculiarities and addictions did not have any relation to body composition in young women with type 1 diabetes and healthy controls.

\section{REFERENCES}

American Diabetes Association (ADA). (2011). Diagnosis and classification of diabetes mellitus, Diabetes care, 33 (1), S 62-69.

American Diabetes Association (ADA). (2008). Nutrition recommendations and interventions for diabetes. Diabetes care, 31 (Supl. 1), S 61-78.

Bantle, J. P., Wylie-Rosett, J., Albright, A. L. et al. (2008). Nutrition recommendations and interventions for diabetes: A position statement of the American Diabetes Association. Diabetes Care, 31, S 61-78.

Bray, G. A. (2004). Medical Consequences of Obesity. The Journal of Clinical Endocrinology \& Metabolism, 89 (6), 2583-2589.

Ferreira, M. G., Valente, J. G., Veras, R. M., Silva, G., Sichieri, R. (2008). Alcohol consumption and abdominal fat in blood donors. Rev Saúde Pública, 42 (6), 1-6.

Ingberg, C. M., Särnblad, S., Palmer, M. et al. (2003). Body composition in adolescent girls with type 1 diabetes. Diabetic medicine, 20 (12), 1005-1011.

Jitnarin, N., Kosulwat, V., Boonpraderm, A., Haddock, C. K. (2008). The relationship between smoking, BMI, physical activity, and dietary intake among Thai adults in central Thailand. Journal of the Medical Association, 91 (7), 1109-1116.

Kadziauskienė, K., Bartkevičiūtè, R., Olechnovič, M. (1999). Suaugusiu Lietuvos žmoniu gyvensenos ir faktiškos mitybos tyrimas. Vilnius: Respublikinis mitybos centras.

Kershnar, A. K., Daniels, S. R., Imperatorem, G. et al. (2006). Lipid abnormalities are prevalent in youth with type 1 and type 2 diabetes: The SEARCH for Diabetes in Youth Study. Journal of Pediatircs, 149, 314-319.

Krishnan, S., Copeland, K. C., Bright, B. C. et al. (2011). Impact of type 1 diabetes and body weight status on cardiovascular risk factors in adolescent children. Journal of Clinical Hypertension, 13 (5), 351-356.

Margeirsdottir, H. D., Larsen, J. R., Brunborg, C., Overby, N. C., Dahl-Jorgensen, K. (2008). High prevalence of cardiovascular risk factors in children and adolescents with type 1 diabetes: A population-based study. Diabetologia, 51, 554-561.

Mehta, S. N., Volkening, L. K., Anderson, B. J. et al. (2008). Dietary behaviors predict glycemic control in youth with type 1 diabetes. Diabetes Care, 31, 13181320. 
Muth, N. D. (2011). The American Council on Exercise. What are the Guidelines for Percentage of Body Fat Loss. Internet link: http://www.livestrong.com/ article/400289-american-council-on-exercise-body-fatpercentage/

Norkus, A., Baliutavičienè, D., Danytè, E., Žalinkevičius, R. (2007). Cukrinio diabeto diagnostika ir mitybos ypatumai. Kaunas.

Overby, N. C., Flaaten, V., Veierod, M. B. et al. (2007). Children and adolescents with type 1 diabetes eat a more atherosclerosis-prone diet than healthy control subjects. Diabetologia, 50, 307-316.

Patton, S. R., Dolan, L. M., Powers, S. W. (2007). Dietary adherence and associated glycemic control in families of young children with type 1 diabetes. Journal of American Diet Association, 107, 46-52.

Ritchie, L. D. (2012). Less frequent eating predicts greater BMI and waist circumference in female adolescents. The American Journal of Clinical Nutrition, 95 (2), 290-296.
Särnblad, S., Ingberg, C. M., Aman, J., Schvarcz, E. (2007). Body composition in young female adults with Type 1 diabetes mellitus. A prospective case-control study. Diabetic Medicine: A Journal of the British Diabetic Association, 24 (7), 728-734.

Silverstein, J., Klingensmith, G., Copeland, K. et al. (2005). Care of children and adolescents with type 1 diabetes: A statement of the American Diabetes Association. Diabetes Care. 28, 186-212.

Stukas, R., Dobrovolskij, V. (2009). Visuomenès sveikatos studentų mitybos ypatumai. Sveikatos mokslai. 1, 2147-2153.

Urbanavičiūtė, A. Šapoka, V. Urbanavičius, V. (2010). Cukriniu diabetu sergančių pacientų mirtingumo rodikliai Lietuvoje. Gerontologija, 11 (2), 103-110.

Welborn, T. A. (2003). Waist-hip ratio is the dominant risk factor predicting cardiovascular death in Australia. Medical Journal of Australia, 179, 580-585.

\title{
SERGANČIŲJŲ 1 TIPO CUKRINIU DIABETU IR SVEIKŲ 18-25 METŲ AMŽIAUS MERGINŲ MITYBOS YPATUMAI IR ŽALINGI İROČIAI BEI JŲ SĄSAJA SU KŪNO KOMPOZICIJA
}

\author{
Sandrija Čapkauskienė, Daiva Vizbaraitė, Joana Garlavičiūtė, NilanaVaitkevičiūtė \\ Lietuvos kūno kultūros akademija, Kaunas, Lietuva
}

\section{SANTRAUKA}

Tyrimo pagrindimas ir hipoteze. Mitybos terapija yra svarbi cukrinio diabeto prevencija ir cukrinio diabeto kontrolès dalis, diabeto komplikacijų išvengimo ar sumažinimo prevencinė priemonè. Manoma, kad mityba ir žalingi ịpročiai turi įtakos merginų, sergančių 1 tipo cukriniu diabetu, kūno kompozicijai.

Tikslas - ivvertinti sergančiujų 1 tipo cukriniu diabetu ir sveikų 18-25 metų merginų kūno kompoziciją, mitybos ypatumus ir žalingus ipročius, nustatyti jų tarpusavio sąsajas.

Metodai. Buvo tiriamos 24 sveikos (amžiaus vidurkis - 20,2 $\pm 1,2 \mathrm{~m}$.) ir 141 tipo cukriniu diabetu sergančiu merginu (amžiaus vidurkis $-21,9 \pm 0,8 \mathrm{~m}$.). Atlikti antropometriniai matavimai, anketa ịvertinti faktinės mitybos ir gyvensenos ypatumai bei žalingi ipročiai.

Rezultatai. KMI reikšmè, liemens apimtis ir klubų santykis statistiškai reikšmingai didesni buvo sergančiuju 1 tipo $\mathrm{CD}(\mathrm{p}<0.05)$. 86\% sergančiujų 1 tipo $\mathrm{CD}$ ir $58 \%$ sveikų merginų maistui gaminti vartoja augalini alieju $(\mathrm{p}<0.05) .50 \% 1$ tipo diabetu sergančiujų ir tik $4 \%$ sveikų merginų valgo reguliariai $(\mathrm{p}<0.05)$. Žalingų ipročiu pasireiškimas tarp grupių nesiskyrè $(\mathrm{p}>0.05)$. Visų tiriamujų kūno kompozicijai mitybos ypatumai ir žalingi ipročiai itakos neturejo.

Aptarimas ir išvados. KMI buvo normalus, tačiau merginų, sergančiu 1 tipo cukriniu diabetu, šis rodiklis buvo reikšmingai didesnis nei sveikų bendraamžiu. Liemens apimtis bei liemens ir klubų santykis taip pat reikšmingai didesnis buvo merginų, sergančiu 1 tipo cukriniu diabetu. Sergančiosios 1 tipo diabetu valgo dažniau nei sveikos merginos. Maistui gaminti abi tiriamuju grupès vartoja augalinį aliejų. Sveikos merginos buvo reikšmingai labiau priklausomos nuo produktų, išaugintų asmeniniame ūkyje. Vertinant žalingus ipročius, reikšmingo skirtumo tarp tiriamų grupių nepastebèta. Visų tiriamujų kūno kompozicijai mitybos ypatumai ir žalingi ipročiai įtakos neturèjo.

Raktažodžiai: antropometriniai duomenys, klausimynas, rūkymas, alkoholis.

Gauta 2012 m. gegužès 29 d.

Received on May 29, 2012

Priimta $2012 \mathrm{~m}$. birželio $8 \mathrm{~d}$.

Accepted on June 8, 2012
Corresponding author Sandrija Čapkauskienė Lithuanian Academy of Physical Education Sporto str. 6, LT-44221 Kaunas

Lithuania

Tel +37065515636

E-mail capkauskiene@gmail.com 